414 First experience with the St Jude Medical, Inc, Symmetry Bypass System (Aortic Connector System)

L. Hornik, G. Tenderich, K. Minami, D. Fassbender,

T. O. Schulz, B. Beinert, and R. Koerfer

417 The last to die is hope: Prolonged mechanical circulatory support with a Novacor left ventricular assist device as a bridge to transplantation

D. Casarotto, T. Bottio, A. Gambino, L. Testolin, and G. Gerosa

419 Successful clinical application of tissueengineered graft for extracardiac Fontan operation

Y. Naito, Y. Imai, T. Shin'oka, J. Kashiwagi, M. Aoki,

M. Watanabe, G. Matsumura, Y. Kosaka, T. Konuma,

N. Hibino, A. Murata, T. Miyake, and H. Kurosawa

421 Unintended right-to-left shunt after Fontan operation: Consequence of unligated vertical vein in a child with total anomalous pulmonary venous drainage, single ventricle, and heterotaxy

D. Mishaly, J. Hegesh, M. Frand, A. Smolinsky, and G. Amir

423 Mitral annular and left ventricular outflow tract enlargement with autologous tissue: Extended application of the Ross-Konno procedure J. M. Caffarena, M. Rovirosa, and J. M. Gòmez-Ullate
426 Methylene blue during cardiopulmonary bypass to treat refractory hypotension in septic endocarditis

M. Grayling and C. D. Deakin

428 Preoperative chemotherapy is essential for conservative surgery of Askin tumors

G. Veronesi, L. Spaggiari, T. De Pas, P. G. Solli,

F. De Braud, G. P. Catalano, G. Curigliano, F. Leo, and U. Pastorino

430 Potential for detrimental hyperinflation after lung transplantation with application of negative pleural pressure to undersized lung grafts

B. D. Kozower, B. F. Meyers, A. M. Ciccone, T. J. Guthrie, and G. A. Patterson

432 Resection of anterior mediastinal tumor through a ministernotomy: Preliminary experience with ten cases

P. Icard, O. Le Page, M. Massetti, B. Alkofer,

J. P. Le Rochais, and A. Khayat

434 Aggressive multimodality treatment of invasive thymic carcinoma

M. A. Greene and M. A. Malias

437 Combined therapy with inhaled nitric oxide and intravenous epoprostenol (prostacyclin) for critical pulmonary perfusion after the Fontan procedure

K. Miyaji, N. Nagata, T. Miyamoto, and K. Kitahori

\title{
Cover Photograph
}

The cover figure shows echocardiographic assessment of left ventricular function in rats at 32 weeks after myocardial infarction $(M I)$ and transplantation of mouse embryonic stem (ES) cells. The anterior and posterior walls were hypokinetic and the cavity of the left ventricle was dilated in the postinfarcted heart with intramyocardial injection of the cell-free medium (upper panel, $M I+$ Medium). The enlarged ventricular cavity showed a significant decrease in anterior and posterior wall thickness and subsequently caused a reduction of endocardial and midwall fractional shortening. Compared to the MI heart with injection of the cell-free medium, intramyocardial transplanta- tion of ES cells improved ventricular wall contractility and reduced the left ventricular dilation (lower panel, $M I+E S$ Cells). The anterior and posterior walls of the left ventricle were thicker in the MI area with cell transplantation. Yong-Fu Xiao, $M D, P h D$

\section{Reference}

1. Min JY, Yang Y, Sullivan MF, Ke Q, Converso KL, Chen $\mathrm{Y}$, et al. Long-term improvement of cardiac function in rats after infarction by transplantation of embryonic stem cells. J Thorac Cardiovasc Surg. 2003;125:361-9. 